\title{
ISOLATION FROM SOIL OF BACTERIA PRODUCING EXTRACELLULAR ALPHA GALACTOSIDASE
}

\author{
M.A. LOKUGE and C. DEEPAL MATHEW* \\ Department of Biochemistry \& Molecular Biology, Faculty of Medicine, University of Colombo, \\ Colombo
}

(Received: 29 December 1999 ; accepted: 20 October 2000)

\begin{abstract}
Extracellular alpha galactosidase (alpha galactosidase galactohydrolase EC 3.2.1.22) producing bacteria were isslated firom soil by the enrichment culture technique using raffinose as the inducer: Six bacterial species were isolated hy this method hased on their morphological characteristics. Their raffinose utilization rate varied from $11 \mathrm{mg} / \mathrm{h}$ to $27 \mathrm{mg} / \mathrm{h}$. Enzyme acivity present in the supernatant varied from 2-11 $\mathrm{mU} / \mathrm{ml}$. Two of the isolated species did not show any alpha galactosidase activity. Three bacterial species having high alpha galactosidase activity were identified as Klehsiella menmoniue, Citrobucter freumclii and Escherichio coli by their colony morphology and biochemical tests. They were cultivated at different pH values with peptone and ammonium sulphate as the nitrogen source. From those studies, it was shown that the highest extracellular alpha galactosidase. activity of $14.7 \mathrm{mU} / \mathrm{ml}$ could be obtained from Citrobucter fremndii after 18 h of cultivation in a culture medium with an initial $\mathrm{pH}$ of 8 containing peptone as the nitrogen source. Extracellular enzyme production was increased up to $19 \mathrm{mU} / \mathrm{ml}$ by the cultivation of Citrobucter frenndii in $\mathrm{pHs}$ phosphate buffer for $36 \mathrm{~h}$ with peptone as the nitrogen source.
\end{abstract}

Key Words: Alpha gralactosidase, Citrobucter freun.rlii, extrace]lular, raffinose hydrolysis

\section{INTRODUCTION}

Alpha galactosidase (alpha-D-galactoside galactohydrolase EC 3.2.1.22) is an exocarbohydrase. It hydrolyses the terminal alpha 1-4 galactosidic linkages of galactose containing oligosaccharides and polysaccharides.

Alpha galactosidase has been reported to occur widely in microorganisms, plants and in animals. ${ }^{1}$ This enzyme is required for the degradation of galactomannans and the reserve oligosaccharides during seed germination. ${ }^{2}$

It has been isolated from several bacterial species e.g. Bacillus subtilis," Bacillus stearothermophilus, ${ }^{4}$ Klebsiella sp. No. PG-2 $2^{5}$ and also from many species of fungi e.g. Mortierella vinacea, ${ }^{6}$ Monascus pilosus, ${ }^{7}$ Trichoderna reesei Rut C-30. ${ }^{8}$

Industrial applications of alpha galactosidase are in beet sugar industry, soy milk processing, pulp and paper industry and manufacture of gelling agents. Attempts have been made in medicine to use alpha galactosidase in the treatment

*Corresponding author. 
of Fabry's disease. In industrial applications, fungi and bacteria are used as the enzyme source as they can be easily grown and it is usually not difficult to scale up the production process. There is no seasonal variation in the enzyme production with microorganisms. The majority of enzymes that have so far been used in industry are extracellular enzymes produced by microorganisms. With microbial enzymes, it is often possible to increase the yield by changes in the growth conditions, addition of inducers, or strain selection including increasing the number of gene copies by genetic engineering.

In this paper we report the isolation of extracellular alpha galactosidase producing bacteria from soil by using raffinose as the inducer and the optimization of alpha galactosidase production.

\section{METHODS AND MATERIALS}

Materials: Analytical grade Serva Fein Biochemicals and Sigma Chemicals were used. Absorbance measurements were carried out using a Shimadzu UV 120-02 spectrophotometer. A bench centrifuge (MSE) and a high speed (Beckman model J2-21) centrifuge were used for centrifugation. Fisherbrand Hydrus $300 \mathrm{pH}$ meter was used for $\mathrm{pH}$ measurements. Sterilization of culture media was done by autoclaving them at $121^{\circ} \mathrm{C}$ for 15 minutes.

Enzyme Assay: To $1 \mathrm{ml}$ of culture supernatant, $1 \mathrm{ml}$ of $0.15 \mathrm{M}$ McIlvaine buffer (pH 5.0) was added and mixed well. $1 \mathrm{ml}$ of this mixture was incubated with $0.5 \mathrm{ml} 1 \mathrm{mM}$ p-nitrophenyl alpha-D-galactophyranoside solution for 30 minutes at $29^{\prime \prime} \mathrm{C}$. The reaction was terminated by the addition of $5 \mathrm{~m}]$ of $1.0 \mathrm{~N} \mathrm{Na}_{2} \mathrm{CO}_{3}$ solution. Absorbance was measured at $405 \mathrm{~nm}$. In enzyme assays at pH $6.0 \& 7.0$, McIlvaine buffer was used.

A unit of enzyme activity is defined as the amount of enzyme that hydrolyses one micromole of substrate per minute under the conditions specified above.

Raffinose Estimation: Raffinose concentration was determined by the method described by Tanaka et al. ${ }^{10}$

Isolation of bacteria producing extracellular alpha galactosidase: Soil samples were collected from topsoil from humus rich places. Soil samples were pooled and approximately $2 \mathrm{ml}$ of soil sample was incubated in a culture medium containing $1 \%$ raffinose, $3 \%$ peptone, $0.05 \%$ yeast extract and $10 \%(\mathrm{v} / \mathrm{v})$ salt solution ( $1 \%$ $\left.\mathrm{K}_{2} \mathrm{HPO}_{4}, 0.9 \% \mathrm{MgCl}_{2} .6 \mathrm{H}_{2} \mathrm{O}, 0.1 \% \mathrm{CaCl}_{2}, 1 \% \mathrm{NaCl}\right)$. pH of the culture medium was adjusted to 7.0 with $0.1 \% \mathrm{NaOH}$. Culture medium $(25 \mathrm{ml})$ in $100 \mathrm{ml}$ conical flasks were incubated at room temperature in an orbital shaker at 115 r.p.m. for four days. After four days, $1 \mathrm{ml}$ of each culture was transferred to a fresh culture medium of the same composition and incubated for two days under the same conditions. 
The process was repeated twice. Afterwards a loopful of culture was transferred on to an agar plate containing the same culture medium solidified with $3 \%$ agar and streak plate isolation procedure was performed. Six bacterial species were isolated and inoculated into fresh culture media separately. After $24 \mathrm{hrs}$ cultivation the following parameters were tested with each culture.

(i) Optical Density at $510 \mathrm{~nm}$ (ii) Wet weight (iii) Raffinose Utilization Rate (iv) Enzyme Activity of the supernatant at different $\mathrm{pH}$ values.

Determination of wet weight: The weight of pellets obtained by centrifugation of $10 \mathrm{ml}$ of each bacterial culture at speed 5 for 15 minutes using a MSE bench centrifuge was determined.

Determination of Raffinose Utilization Rate: Before inoculating sterilized enrichment culture medium in different flasks with six bacterial species, $2 \mathrm{ml}$ of culture medium from each flask was taken out for raffinose estimation. After $24 \mathrm{hrs}$ of incubation $2 \mathrm{ml}$ of the supernatant obtained after centrifugation of $10 \mathrm{ml}$ of each culture broth was also subjected to raffinose estimation.

$1 \mathrm{ml}$ of the culture medium without raffinose was used to prepare the blank solution. $1 \mathrm{ml}$ of the culture supernatant to be tested for raffinose estimation was mixed with $1 \mathrm{ml}$ of $0.02 \mathrm{M}$ thio-barbituric acid. $1 \mathrm{ml}$ of concentrated $\mathrm{HCI}$ was added to each mixture and kept in a boiling waterbath for 6 minutes. After cooling, the absorbance was measured at $432.5 \mathrm{~nm}$.

Rafinose utilization rate $\mathrm{mg} / \mathrm{h}$ for each bacterial culture was calculated using the difference obtained for the raffinose contents of each culture medium.

Three selected bacterial species were cultured at $30^{\prime \prime} \mathrm{C}, 45^{\prime \prime} \mathrm{C}$ and $60^{\circ} \mathrm{C}$ and the raffinose utilization rates were measured with each culture.

Identification of the isolated bacterial cultures: Three bacterial species which showed high extracellular alpha galactosidase production were identified by their morphological and biochemical characteristics as described by Barrow and Felthan ${ }^{11}$ and Lennette ${ }^{12}$ as Escherichia coli, Klebsiella pneumoniae and Citrobacter freundii. No tests were done to determine whether the bacteria were pathogenic, as they were isolated from soil.

Optimization of enzyme production by Bacteria: The three bacterial species which were identified as Escherichia coli, Klebsiella pneumoniae and Citrobacter freundii were cultivated in a medium with different nitrogen sources (ammonium sulphate and peptone) and with different initial $\mathrm{pH}$ values 5, 7, 8. A small decrease in initial $\mathrm{pH}$ value was observed after autoclaving. 


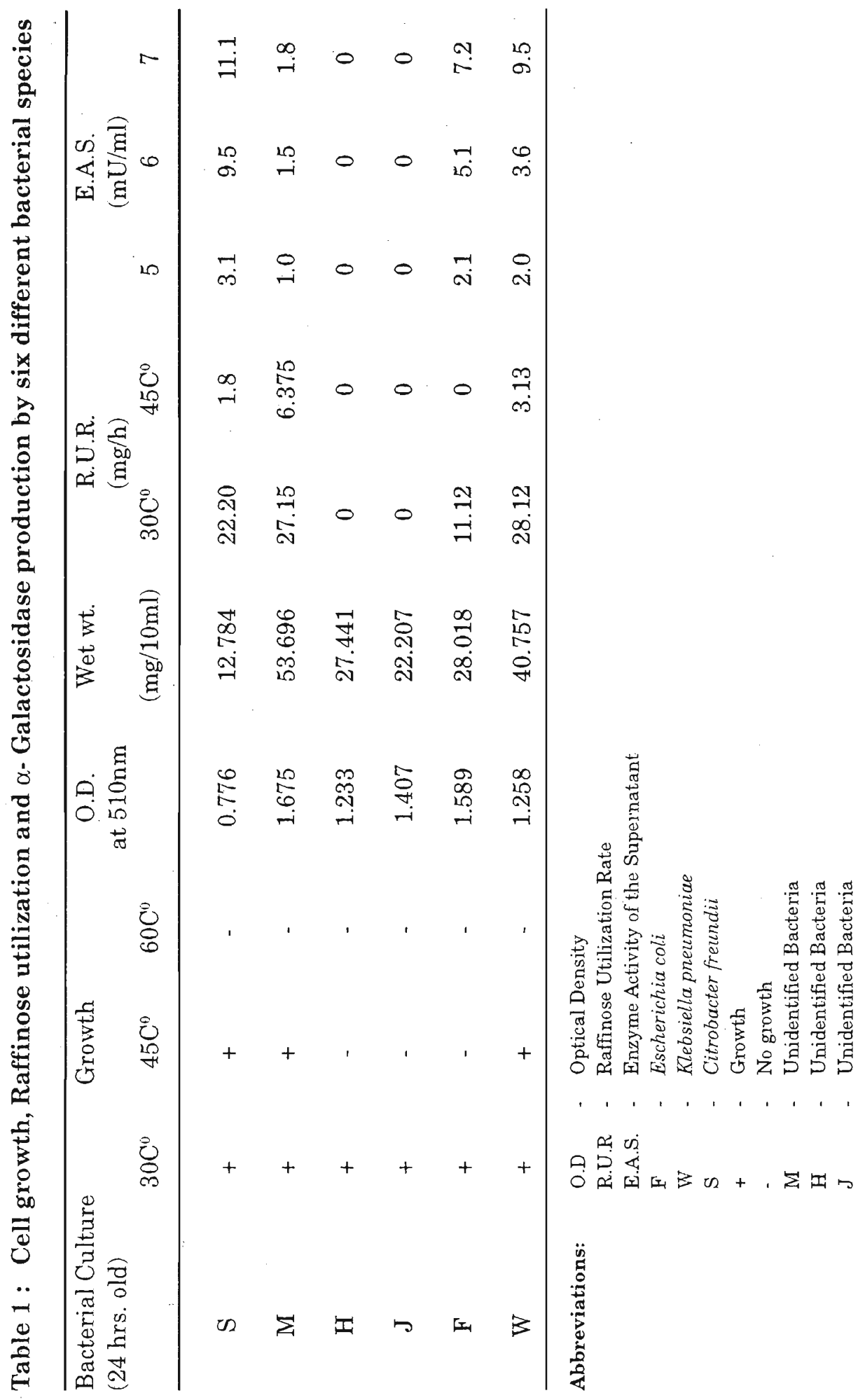


Table 2: Growth Characteristics and Biochemical Test Results for three bacterial species

\begin{tabular}{|c|c|c|c|}
\hline \multirow{2}{*}{$\begin{array}{c}\text { Character/Biochemical } \\
\text { Test }\end{array}$} & \multicolumn{3}{|c|}{ Bacterial Species } \\
\hline & $\mathrm{F}$ & $\mathrm{W}$ & $\mathrm{S}$ \\
\hline \multirow{3}{*}{$\frac{\text { Colony Morphology }}{\text { On Nutrient agar }}$} & Well grown & Large Extremely & Smooth convex \\
\hline & Colourless & mucoid colonies & mucoid colonies \\
\hline & Smooth colonies & & \\
\hline On MacConkey agar & $\begin{array}{l}\text { Large,circular,smooth } \\
\text { pink colonies }\end{array}$ & $\begin{array}{l}\text { Small pink } \\
\text { colonies }\end{array}$ & $\begin{array}{l}\text { Light yellow } \\
\text { colonies }\end{array}$ \\
\hline Motility & Motile & Non-motile & Motile \\
\hline Gram Stain & Gram negative rods & $\begin{array}{c}\text { Gram negative } \\
\text { bacilli }\end{array}$ & $\begin{array}{c}\text { Gram negative } \\
\text { bacilli }\end{array}$ \\
\hline \multicolumn{4}{|l|}{ Biochemical Tests } \\
\hline \multicolumn{2}{|c|}{ Carbohydrate Fermentation Acid, Gas } & Glucose & Acid,Gas \\
\hline Sucrose & $+\mathrm{ve}$ & +ve & + ve \\
\hline Maltose & + ve & $+v e$ & -ve \\
\hline Lactose & + ve & + ve & -ve \\
\hline Mannitol & + ve & +ve & - ve \\
\hline Eesculin Hydrolysis & $-v e$ & ND & ND \\
\hline \multicolumn{4}{|l|}{ Oxidation Fermentation } \\
\hline Glucose & Fermentation & Fermentation & Fermentation \\
\hline \multicolumn{4}{|c|}{ Utilization of Amino Acids } \\
\hline \multicolumn{4}{|c|}{ Decarboxylase : } \\
\hline Lysine & + ve & + ve & -ve \\
\hline Arginine & +ve & $+\mathrm{ve}$ & +ve(48hrs) \\
\hline Ornithine & + ve & +ve(48hrs) & +ve \\
\hline \multicolumn{4}{|l|}{ Deaminase } \\
\hline Phenylalanine & -ve & ND & ND \\
\hline Indole & +ve & -ve & $+\mathrm{ve}$ \\
\hline Methyl Red & $+\mathrm{ve}$ & -ve & + ve \\
\hline Voges-Proskaner & -ve & + ve & -ve \\
\hline Simmon's citrate & -ve & + ve & + ve \\
\hline Hydrogen Sulphide ( $\mathrm{T}$ : & -ve & $-v e$ & + ve \\
\hline Urea & -ve & $+\mathrm{ve}$ & +ve \\
\hline Lead Acetate & $-v e$ & -ve & +ve \\
\hline Catalase & +ve & $+v e$ & $+v e$ \\
\hline Oxidase & -ve & -ve & -ve \\
\hline
\end{tabular}

\begin{tabular}{|c|c|c|}
\hline Symbols & $\begin{array}{l}(+) \\
(-) \\
N D \\
F \\
W \\
\text { W }\end{array}$ & $\begin{array}{l}\text { Positive within 24-48hrs. } \\
10 \% \text { or less positive within 24-48 } \\
\text { Not Determined } \\
\text { Escherichiu colli } \\
\text { Klebsiellu pneumonine } \\
\text { Citrobuster fremondii. }\end{array}$ \\
\hline
\end{tabular}




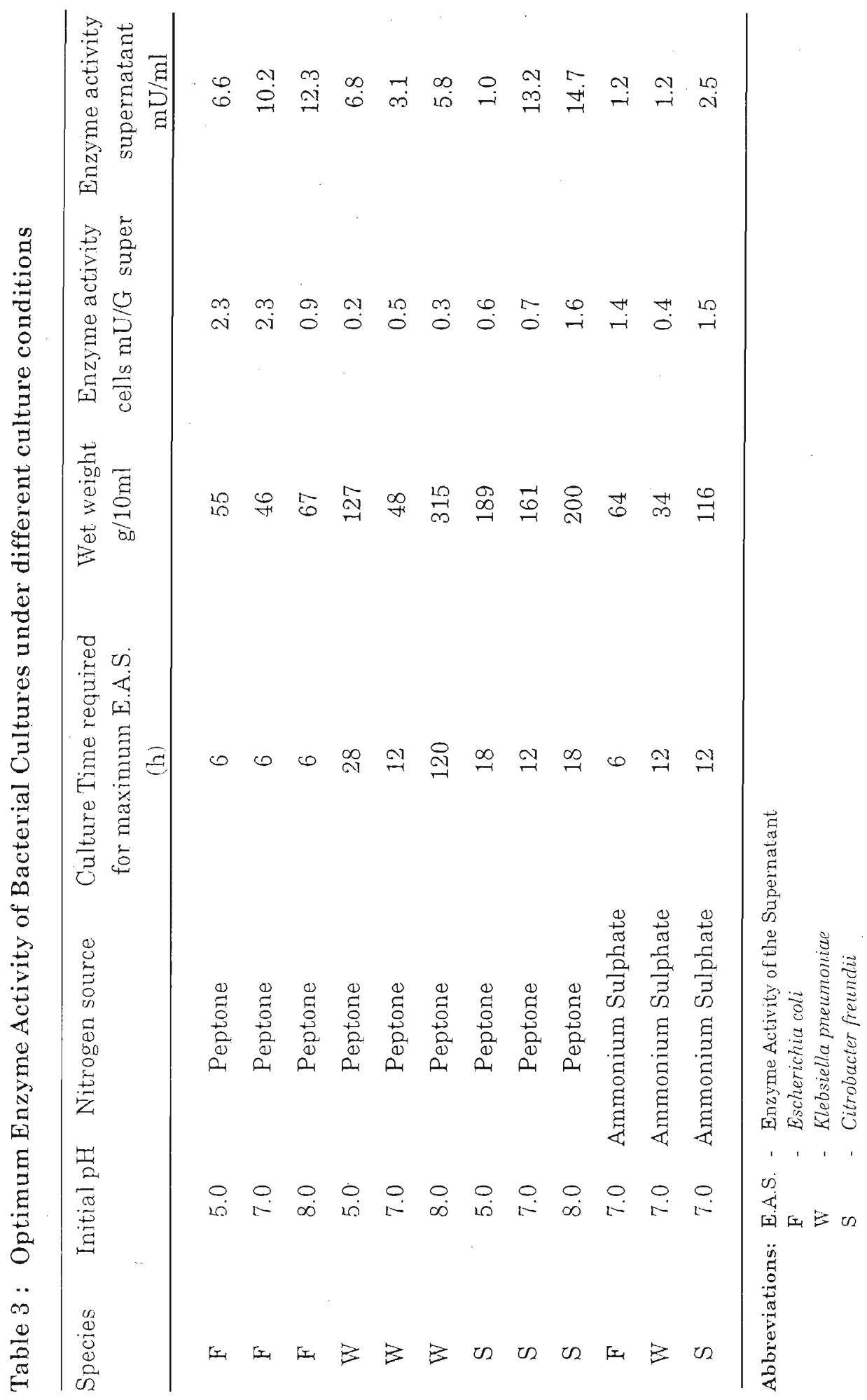


For each bacterial species under each culture condition the following parameters were estimated at $6 \mathrm{~h}$ intervals.
(i) Optical density at $510 \mathrm{~nm}$
(ii) Wet weight
(iii) $\mathrm{pH}$ of the supernatant
(iv) Enzyme activity of the supernatant at, $\mathrm{pH} 7$.
(v) Enzyme activity of the cells at $\mathrm{pH} 7$.

Culture medium was the same as used in the isolation of bacteria. Culture volume was $500 \mathrm{ml}$ (culture flasks 2L) and cultures were inoculated with $50 \mathrm{~m}$ ) of bacteria culture medium cultivated for $24 \mathrm{~h}$. Cultures were incubated in an orbital shaker at a speed of $115 \mathrm{rpm}$ at room temperature. $20 \mathrm{ml}$ samples were removed at $6 \mathrm{~h}$ intervals aseptically using a laminar flow. 3\%ammonium sulphate was used instead of $3 \%$ peptone when ammonium sulphate was used as the nitrogen source.

Enzyme activity of the cells: Enzyme activity of the cells was determined by washing the pellet obtained from wet weight determination in $0.15 \mathrm{M} \mathrm{McIlvaine} \mathrm{buffer} \mathrm{(pH7).}$ The pellet was suspended in final volume of $2 \mathrm{~m}$ ] using $0.15 \mathrm{M}$ Mcllvaine buffer ( $\mathrm{pH} 7$ ) and $0.1 \mathrm{ml}$ if this suspension was incubated with $0.4 \mathrm{ml}$ of $0.15 \mathrm{M}$ Mcllvaine buffer (pH7) and $0.5 \mathrm{ml} 10 \mathrm{mM}$ p-nitrpheny1-alpha-D-galactpyranoside solution for 30 minutes at $29^{\circ} \mathrm{C}$. The reaction was terminated by adding $5 \mathrm{ml}$ of $0.1 \mathrm{~N} \mathrm{Na}_{2} \mathrm{CO}_{3}$ solution. Absorbance was measured at 405mm, using a Shimadzu UV 120-02 spectrophotometer.

C. freundii was also grown on a culture medium containing pH 8 phosphate buffer and the above parameters were estimated at 6 h intervals.

\section{RESULTS}

Six bacterial species were isolated from soil samples after cultivation for an initial period of four days and cultivation in fresh culture medium for two days three times. The bacterial species were labelled as S,M,H, G,F and W. Detailed studies indicated that supernatant of species $\mathrm{H}$ and $\mathrm{J}$ have no enzyme activity (Table 1 ). They also do not utilize raffinose. Other four bacterial species have extracellu]ar enzyme activity. Their raffinose utilization rate varied from $11-28 \mathrm{mg} / \mathrm{h}$ (Table 1 ). In all cases, the enzymes showed high activity at neutral $\mathrm{pH}$. The lowest wet weight and highest activity of $11 \mathrm{mU} / \mathrm{m}$ l were observed in Citrobacter freundii.

The three species which showed high production of extracellular enzyme were identified as E. coli, Citrobacter freundii and Klebsiella pneumoniae (Table 2).

According to the results obtained from three bacterial species grown in the culture medium containing ammonium sulphate, Citrobacter freundii gave the highest enzyme production of $2.5 \mathrm{mU} / \mathrm{ml}$ after $12 \mathrm{~h}$ of cultivation when compared 


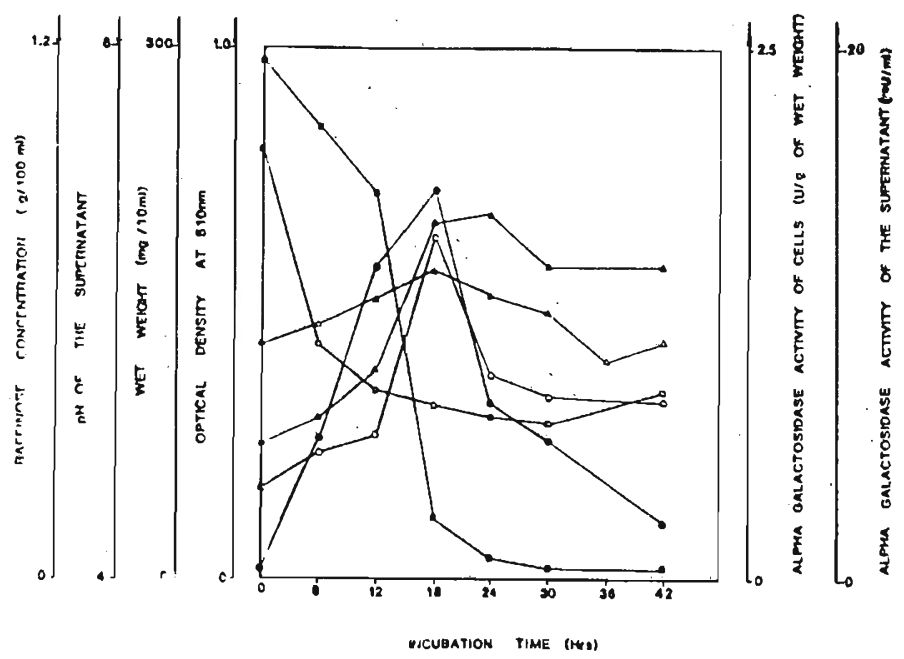

Figure 1: Alpha galactosidase production by Citrobacter freundii grown in peptone culture medium with an initial $\mathbf{p H}$ of 8 .

Symbols : (A) Wet weight

(A) Raffinose concentration

(-) Alpha galactosidase activity of the supernatant at $\mathrm{pH} 7$

(D) Alpha galactosidase activity of the cells at $\mathrm{pH} 7$
(•) Optical density at $510 \mathrm{~nm}$

(O) $\mathrm{pH}$ of the supernatant

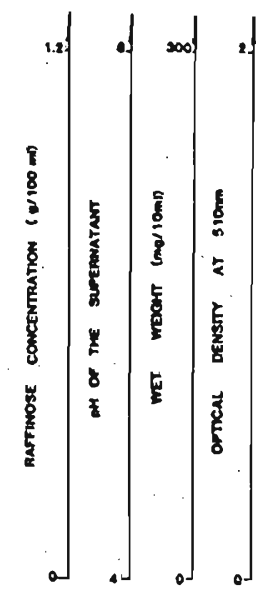

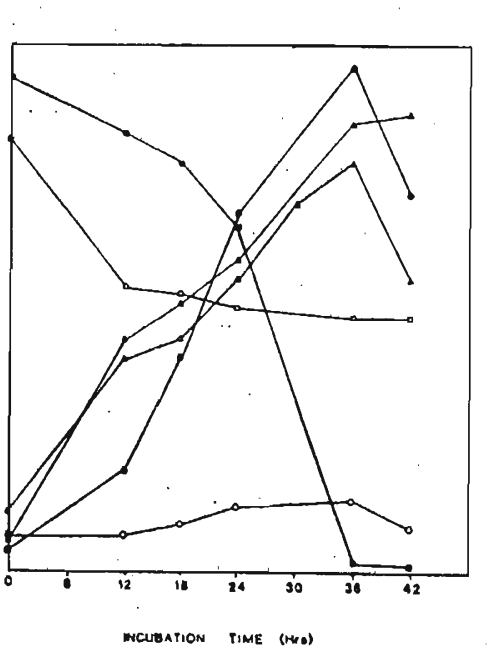

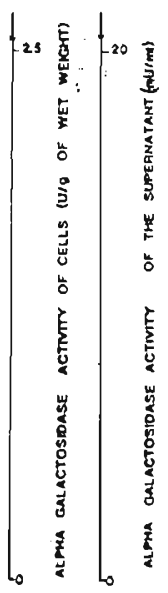

Figure 2: Alpha galactosidase production by Citrobacter freundii grown in pH 8 phosphate buffer culture medium containing peptone.

Symbols :

(A) W'! weight

( $\triangle$ ) Raftinose concentration

(•) Optical density at $510 \mathrm{~nm}$

(O) $\mathrm{pH}$ of the supernatant

(a) Alphagalactosidase activity of the supernatant at $\mathrm{pH} 7$

(口) Alpha galactosidase activity of the cells at $\mathrm{pH} 7$ 
with highest activity of $1.2 \mathrm{mU} / \mathrm{ml}$ for E.coli and Klebsiella pneumoniae at $6 \mathrm{~h}$ and $12 \mathrm{~h}$ of cultivation respectively (Table 3 ). Inorganic nitrogen has led to poor cell growth and low alpha galactosidase production when grown in culture medium with peptone as the nitrogen source. With different initial $\mathrm{pH}$, again higher enzyme production of $14.7 \mathrm{mU} / \mathrm{ml}$ was observed with $C$. freundii after $18 \mathrm{~h}$ of cultivation at $\mathrm{pH} 8.0$ (Figure 1). The enzyme production could be further increased up to $19 \mathrm{mU} / \mathrm{ml}$ after $36 \mathrm{~h}$ when grown in $\mathrm{pH} 8$ phosphate buffer (Figure 2). As shown in the graph, the pH of the medium does not change significantly with time as observed under other culture conditions.

\section{DISCUSSION}

In this study, initial $\mathrm{pH}$ of the medium was adjusted to 7 because most bacteria grow well at neutral $\mathrm{pH}$ values and also earlier reports showed that bacterial alpha galactosidases are more stable at neutral $\mathrm{pH}$ values. ${ }^{13}$ Raffinose was used as the inducing sugar in the medium. The results show that $C$. freundii grown in $\mathrm{pH} 8$ phosphate buffer culture medium containing peptone as the nitrogen source is suitable for the production of extracellular alpha galactosidase. In future studies the alpha galactosidase from $C$. freundii will be purified and characterized to determine its suitability as an industrial enzyme for removal of raffinose sugars from food products.

\section{Acknowledgment}

The authors thank Prof. Jennifer Perera, Dept. of Microbiology, Faculty of Medicine, University of Colombo for assisting in the identification of bacterial species.

\section{References}

1 Bishop D.F. \& Desnick R.J. (1981). Affinity purification of alpha galactosidase from human spleen, placenta and plasma with elimination of pyrogen contamination. Journal of Biological Chemistry 256:1307-1316

2 Dey P.M. \& Pridham J.B.(1968): Multiple forms of alpha galactosidase in Vicia faba seeds. Phytochemistry 7:1137-1139

3 Overbeeke N., Giuseppin M.L.F., Underwood D.R. \& Verribs C.T. (1990). Secretion of alpha galactosidase from Cymopsis tetragonoloba (Guaar) by Bacillus subtilis. Applied and Environmental Microbiology 56:1429-1434.

4 Talbot G. \& Sygusch T. (1990). Purification and characterization of thermostable beta mannase and alpha galactosidase from Bacillus stearothermophilus. Applied and Environmental Microbiology 56 : 3505-3510. 
5 Shah V. \& Parekh L.J. (1987). Purification and properties of alpha galactosidase from Klebsiella sp: No PG2. Indian Journal of Biochemistry and Biophysics 27:103-107.

6 Suzuki H., Li S. \& Li Y. (1970). Alpha galactosidase from Morticrella vinacea. Journal of Biological Chemistry 245: 781-786.

7 Wong Y.L., Fong W.F. \& Lam W.L. (1993). Production of alpha galactosidase by Monascus grown on soybean and sugar cane waste. World Journal of Biotechnology 9: 529-533.

8 Zeilingar S., Kristujek D., Arisan A.T., Hodits R. \& Kubicek C.P. (1993). Conditions of formation, purification and characterization of an alpha galactosidase of Tricroderma reesei RUT C-30 Applied and Environmental Microbiology, 59: 1347-1353.

9 Osada T., Kurods Y. \& Ikai A. (1987). Endrocytotic internalization of alpha 2 macroglobulin : alpha galactosidase conjugate by cultured fibroblasts derived from fabry hemizygote. Biochemistry Biophysics Research Communications 142(1): $200-206$

10 Tanaka M., Thananubku] D., Lee T.C. \& Chichester O. (1975). A simplifjed method for the quantitative determination of sucrose, raffinose and stachyose in legume seeds, Journal of Fond. Science 40: 1087-1088

11 Barrow G.I. \& Feltham R.K.A. (Ed.) (1993). Cowan and Steels Manual for identification of medical bacteria. Cambridge University Press, Cambridge.

12 Lennette E.H. (1985). Manual of Clinical Microbiology, American Society for Microbiology, Washington D.C.

13 Nagao Y., Nakada T. \& Imoto M. (1988). Purification and analysis of structure of alpha galactosidase from Escherichia coli. Biophysics Research communications 151: 230-241. 